\title{
14-143-12 超音波送受信器を用いた就寝時の生体モニタリング
}

Study on biomonitoring during sleep utilizing utrasonic tranceducers

○谷城 博幸*1, 梅田 和弘 ${ }^{* 2}$, 吉川 和博*2, シャハリアル・アハメド*3, 舟久保 昭夫*2, 福井 康裕 ${ }^{* 2}$

*1 東京電機大学 理工学部 電子情報工学科,

*2 東京電機大学大学院 理工学研究科 電子情報工学専攻, *3 新潟産業大学 経済学部 産業学科

\section{Hiroyuki Tanishiro*1, Kazuhiro Umeda*2, Kazuhiro Yoshikawa*2, Shahriar Ahmed ${ }^{\star 3}$, Akio Funakubo ${ }^{\star 2}$, Yasuhiro Fukui ${ }^{\star 2}$ \\ *1 Tokyo Denki University, *2 Graduate School of Tokyo Denki University, ${ }^{\star 3}$ Niigata Sangyo University}

\section{【はじめに】}

現在，自分自身の健康に気を使うホームヘルスケアに対 する意識は高まっている，例えば，電子血圧計・電子体温 計・体脂肪計などは安価な機器として市販され, それらを 利用することで, 家庭内で日常的に測定可能な生体情報 （血圧, 体温, 体脂肪など）から自分の健康状態を知るこ とも簡単になった. ホームヘルスケアに必要とされる生体 情報の計測条件は, 非侵襲的で, 出来る限り拘束を伴わ ず，日常的に簡易に行えることである.しかしながら，こ の条件に見合う生体情報となると，医療技術の進んだ現在 でも，前述の血圧・体温などのごく一部の生体情報に限ら れている.

予防医学において，ホームヘルスケアは重要な意味をも っており，前述したように，病気にかかる前に自分自身の 健康状態をはかるだけではなく，万が一病気にかかった場 合などには，ホームヘルスケアで得られた生体情報がその 後の治療における有効な情報となりうる.

本研究では，従来の生体情報に加えて，ホームヘルスケ アに必要とされる新たな生体情報を得るための基礎的な検 討を行うことを目的としている．これまでに我々は，超音 波送受信器を利用した, 非接触型の就寝時の体動・呼吸計 測としたシステムの構筑を行い, このシステムの体動・呼 吸計測の基礎的な評価を行った。その結果，今後におい て，有効な生体情報が得られる可能性が示唆された。

本報告においては，これまでに開発された超音波送受信 機による体動・呼吸計測システムを用いて，長期にわたる 睡眠時の呼吸・体動パターンの獲得を行うことを主な目的 とした。また，睡眠前後の血圧や体温など，他の生体情報 と総合的に判断することにより，睡眠時の肉体的・精神的 疲労の解消度などとの関連性について基礎的な検討を行う ことを試みた。

\section{【システム構成】}

本システムは，超音波送受信器（T/R40-16, 日本セラミ ック（株）），送受信器の駆動回路, 受信波形解析用PIC マイコンおよび無線送信ユニット（RS232-STR，野村エン ジニアリング（有））からなる呼吸・体動計測装置と，無 線受信ユニット（RS232-STR，野村エンジニアリング（ 有））およびノートパソコン（Amity CN，三菱電機（株 ））からなるデータロガーから構成されている，本システ ムの概略図をFig.1に示した。

$40 \mathrm{kHz}$ の矩形パルス 8 周期分 $(0.32 \mathrm{~ms})$ の信号を送信器 に与えることによって送信波を生成し，送信波を被験者に 対して放射する（Fig.2）．胸部や布団から反射された反射 波を受信器で65ms間計測した．送信信号と受信信号の遅延 時間から距離計測を行うこともできるが，呼吸による数 $\mathrm{cm}$

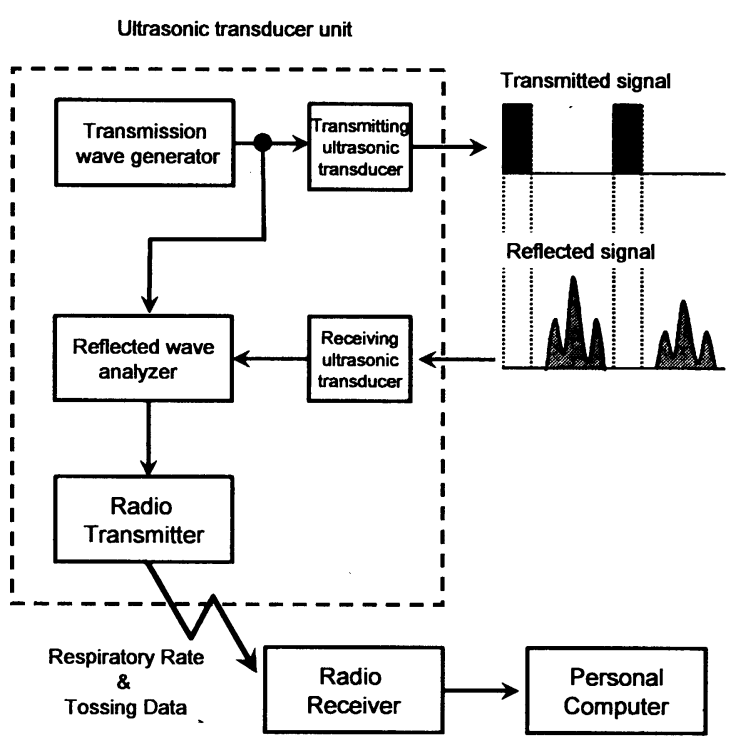

Fig.1 Respiratory and Tossing Monitoring System 


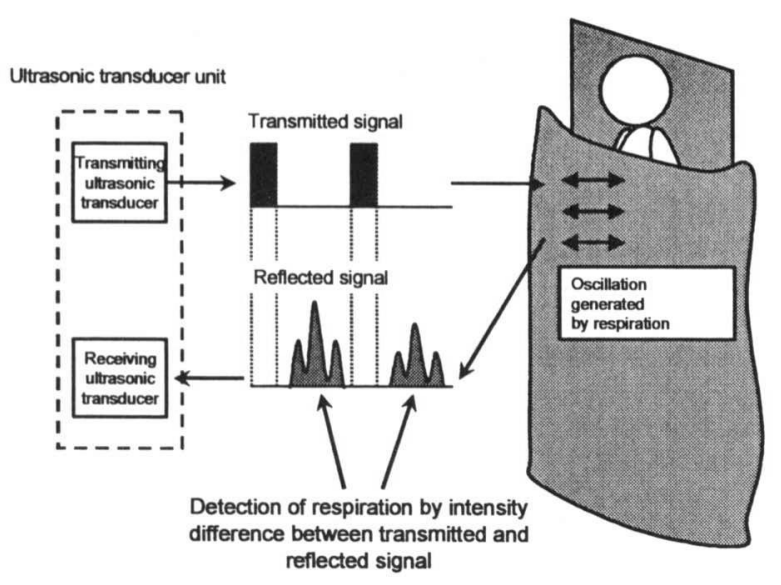

Fig.2 Respiratory Measuring Method

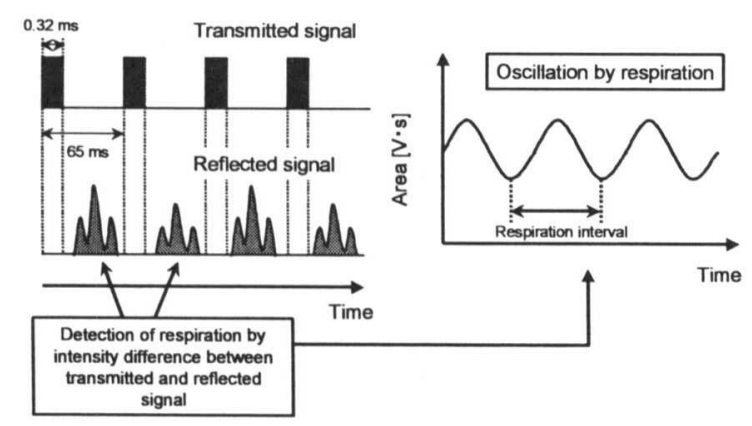

Fig.3 Analysis of Respiration

の距離変化を計測することは難しい. 一方, 反射波は 3 次 元的に空間を伝搬してくるため, 受信信号は複数の面から の反射波を重畳したものからなり，反射面の起伏は受信信 号の包絡線の形状に反映されている.

そこで，65ms毎の受信信号の包絡線形状をサンプリング するために，PICマイコンを用いてローパスフィルタ $(5 \mathrm{kHz})$ を通して, $10 \mathrm{KHz}$ のサンプリング周波数でPICマイ コンによる $\mathrm{A} / \mathrm{D}$ 変換を行い, 呼吸・体動による変動波形 を得た（Fig.3）.

この変動波形より, 一定時間間隔の呼吸回数, 体動の有 無などの検出を行い, 無線送信機からコンピュータへとそ の情報が伝送され保存される.

\section{【方 法】}

ベッド上に寝た被験者の真上 $1.2[\mathrm{~m}]$ 付近に, 呼吸・体動 計測装置を取り付け, 健常男性 1 名による, 就寝状態での 長期呼吸・体動計測を行った。

\section{【結果および考察】}

Fig.4は，寝返りを打つ前，寝返りを打っているとき，寝 返りを打った後の(a)超音波受信器によって計測した受信波 形，(b)ローパスフィルタ $(0.5 \mathrm{~Hz})$ 処理後の (a)波形, (c) 鼻 孔部に取り付けたサーミスタで捉えた呼吸波形，(d)ハイパ スフィルタ $(2 \mathrm{~Hz})$ 処理後の $(\mathrm{a})$ 波形である.

検出の精度という面ではサーミスタを用いた接触計測に は劣っているが, ローパスフィル夕処理後の波形でも呼吸 活動に同期した変動を得ることができた．また，ハイパス フィルタ処理後の波形からは, 体動の有無も確認でき, Fig.4最上部に示したビデオ映像による体動の状態と比較し ても，良好な体動検出が行えうことができた。

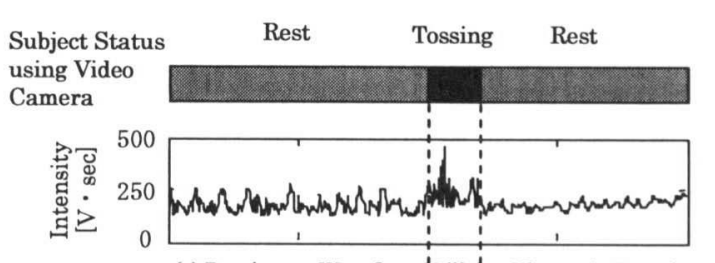

(a) Respiratory Waveform Utilizing Ultrasonic Transducer

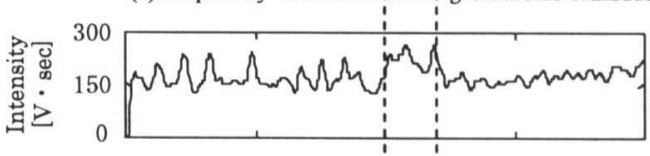

(b) Respiratory Waveform, (Low pass Filtered (a))

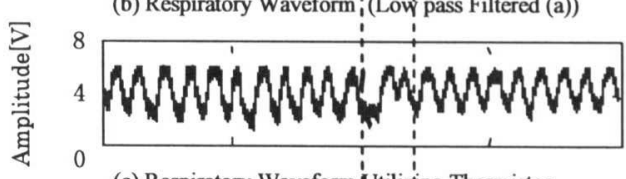

(c) Respiratory Waveform Utilizing Thermistor

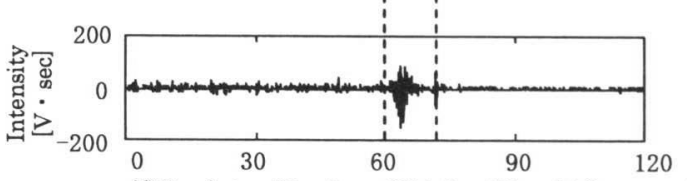

(d) Respiratory Waveform (High Pass Filtered (a)) Time [s]

Fig.4 Measured Waveforms (Respiratory Detection)

\section{【まとめ及び今後の展開】}

本システムを用いることによって, 就寝時における呼 吸・体動の長期計測が可能であることが示唆された。現 在, 他の生体情報（血圧・体温）と併せて, 睡眠時の疲労 回復などとの関倸を調查しており，それらと総合的に判断 することによって, 就寝時における睡眠快適度をはかるこ とができるかを検討中である. 